So that after the death of the muscardic worm, the blood is filled with the thallus in every stage of development. In the latter case, crystals of a perfectly definite form are mixed with the thallus; these are products of some chemical reaction, and are undoubtedly the cause of the rigidity of the dead body of the muscardic worm.

By means of abstractions of the circulating fluid, which are very easily effected, M. Guérin is able to satisfy himself of the state of health of silk-worms, or to predict to the silk-worm cultivator the invasion of such and such diseases; and this is useful, especially in muscardine; for by ceasing to feed those worms which are doomed to an inevitable death, an enormous quantity of mulberry-leaves are œconomized, and the pecuniary loss entailed by such accident is considerably diminished.

The reproduction of the globules of the blood appears to be quite new and of extreme importance in a physiological point of view. It explains very simply the unequal diameters of the globules of the blood of the Invertebrata, and directs us to researches in other species of this extensive group with a view of ascertaining the same facts, and to the Vertebrata themselves to find its analogies. In the latter, the perfect uniformity in the globules of the blood might à priori indicate a want of analogy; but, if real, we must first accurately determine it ; if it be only apparent, we must discover the truth which is still unknown.

On the other hand, we must bear in mind, that in the Vertebrata, the nutritive fluid is met with in different states; the chyle, lymph, and blood. The blood is its ultimate expression, the terminal or perfect state; it is probably not in it therefore that we must seek for these phænomena of degeneration of the globules. Those of the lymph, which are colourless and smaller, have long been regarded as an earlier stage of them. By a coincidence which is at least remarkable in the frog, the triton, and the tortoise, where it has been possible to make observations upon the lymph, the size of the lymphatic globules pointed out by authors is exactly that of the nuclei of the globules of the blood in the same animal ; the shape, certainly, differs, but the relation of size is constant. Lastly, there is a curious fact connected with this question: Schultz, who has observed the formation of the area vasculosa in the embryo of birds, states that the nucleus is the first part which appears; the vesicle being ultimately formed around it.-Gazette des Hôpitaux, Feb. 2, 1850.

BRITISH MUSEUM.

To the Editor of the Annals of Natural History.

SiR,-Having been in the habit of continually using the Natural History collection in the British Museum, never finding any difficulty, and knowing by experience that it is the most completely arranged, and far more easy of access than any other collection in the country, or on the continent, I was surprised to read in the Report of the British Museum Commissioners, the following words as the bases of all their observations on the Department :-

"Being aware from the Memorial presented to the First Lord of the Treasury on the 10th of March 1817, by a very numerous body of 
the cultivators of natural history science, that a wide-spread dissatisfaction prevails among them relative to the actual condition of and means of access to the vast and valuable materials in the Natural History Departments of the British Museum, we have necessarily directed our attention to this subject of complaint." I was induced to look for the memorial, and you may well suppose my astonishment to find that it contains no such complaints, but was entirely devoted to another subject. The words of the memorial are as follows: " $\mathrm{A}$ strong feeling pervades the naturalists of our country that the promotion of the science of natural history is very inadequately provided for by the present constitution of the Trustees of the British Museum." The complaint here made was rectified by the election of Dr. Buckland as a Trustee.

If the other statements of the Commission are no more accurate than the above, their Report cannot be of much value, and the expenses incurred by their three years' occupation is a useless expenditure.-F.R.S.

\section{ECHINOCACTUS EYRIESII.}

Highgate, April 17, 1850.

MY DEAR Sir,-You will remember my calling your attention some time ago to the characters which are assumed by Echinocactus Eyriesii. The artificial divisions which have been made of the Cactaceæ have always seemed to me unsatisfactory. The point is one of some interest to those who conceive, as I confess that I do, that clearness and definiteness of principle in the characterization of genus and species is a matter of much importance to the progress of natural history. I think I can satisfy any reasonable person that Echinocactus Eyriesii cannot be separated from Cereus, if Dame Nature is to be taken as a guide instead of mere arbitrary fancy. I take $E$. Eyriesii alone now, because it seems to be regarded as typical of the genus, and because I have had the longest opportunities of observing it.

I suppose nobody will contend that the mere matter of the time which it takes for a plant (or anything else) to reach maturity and its characteristic form, is to fix the determination of genus. This may, when strongly marked, be well enough for a specific distinction, but it cannot, surely, yield a generic one. Else, on every principle of logic, each different kind of Cereus must make a different genus. If two plants, belonging to the same family, and in the characters of whose flowers no essential distinction can be pointed out, assume, when arrived at mature age, a tendency to a similar habit, it seems to me that we get only into confusion, and make all classification mere moonshine, if we do not put them into the same genus.

Now to my friend Echinocactus Eyriesii. And I call it my friend, because, though not by any means a frequent denizen of the greenhouse, I am sure it ought to be so, if purity, elegance, and fragrance in a flower can give a claim. The gardeners pretend it is a shy bloomer. That must be owing to bad management. I do not know any cactus which is a freer bloomer. I have never passed a year without a constant succession, on the same plant, of its exquisite and delicately fragrant flowers. I have several plants of it. One of 


\section{$2 \mathrm{BHL}$ Biodiversity Heritage Library}

S., F. R. 1850. "British Museum." The Annals and magazine of natural history; zoology, botany, and geology 5, 426-427. https://doi.org/10.1080/03745486009494936.

View This Item Online: https://www.biodiversitylibrary.org/item/61924

DOI: https://doi.org/10.1080/03745486009494936

Permalink: https://www.biodiversitylibrary.org/partpdf/58682

\section{Holding Institution}

University of Toronto - Gerstein Science Information Centre

\section{Sponsored by}

University of Toronto

\section{Copyright \& Reuse}

Copyright Status: NOT_IN_COPYRIGHT

This document was created from content at the Biodiversity Heritage Library, the world's largest open access digital library for biodiversity literature and archives. Visit BHL at https://www.biodiversitylibrary.org. 